\title{
Influenza in pregnant women
}

\author{
Violeta Melinte ${ }^{1,2}$, George Gherlan ${ }^{1,2}$, Ana Maria Veja ${ }^{2}$, Emanoil Ceausu ${ }^{1,2}$

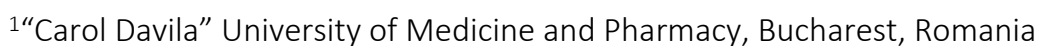 \\ 2"Dr. Victor Babes" Infectious Diseases Hospital, Bucharest, Romania
}

\begin{abstract}
Pregnant and recently postpartum women with influenza are more likely to develop severe illness and die than the general population, based on data from seasonal influenza and from the influenza pandemics of 1918 to 1919,1957 to 1958 , and 2009 to 2010 . The increased severity of influenza in pregnant and recently postpartum women is thought to be related to normal physiologic changes that occur during pregnancy. For example, heart rate and oxygen consumption increase and lung capacity decreases. Because of the increased severity of influenza in pregnancy and the postpartum period, inactivated influenza vaccine is recommended for these women, regardless of trimester of pregnancy. In addition, pregnant and postpartum women with suspected or confirmed influenza should receive prompt empiric treatment with an appropriate antiviral medication.
\end{abstract}

Keywords: pregnancy, influenza, vaccination, antiviral medication

\section{ETIOLOGY}

The common cold virus or influenza virus is part of the Orthomyxoviridae family. It is an enveloped virus, with a variable form but most frequently spherical or filamentous, with a diameter of approximately $50-150 \mathrm{~nm}$, with a linear RNA nucleus with negative polarity. A distinct feature are the proteic membrane spikes represented by haemagglutinin (HA) and neuraminidase (NA) found in a 5:1 ratio (1). There are 18 distinct subtypes of HA and 11 subtypes of NA, used to annually characterize the viral strain types and subtypes involved in seasonal pathologies (eg.: H1N1, H3N2, etc.). The viral strains known to be pathogenic to humans are Influenza A and B - responsible for endemic and pandemic outbreaks - and Influenza $\mathrm{C}$ which determines mild respiratory symptoms (2).

\section{EPIDEMIOLOGY}

Influenza virus infections have a seasonal characteristic. In temperate climates, influenza is re- ported between the months of October until April in the northern hemisphere and between May to September in the southern hemisphere (3). In tropical areas, there are registered cases all through the year, but usually in one or two epidemic episodes per year (4). The seasonal characteristic of influenza is multifactorial, including temperature conditions and humidity in which the virus can develop and multiply, as well as shifts in temperature (cold/ hot, outside/inside) during the cold seasons (5).

Isolated cases as well as well as care facility associated outbreaks are recorded all year round, including during summer months. Epidemic outbreaks usually have a duration of 6 to 8 weeks.

In the USA, during the 2015-2016 season there have been 310.000 cases of hospitalized influenza related respiratory illnesses. In Europe during the same season, there have been 8.500 cases in 8 countries, $70 \%$ of which were determined by Influenza A virus (6).

The influenza viruses can be transmitted to human from birds or pigs, through direct contact with 
the sick animals or through contact with objects or water contaminated with animal excrements. Adequate thermic preparation is mandatory to diminish the risk of infection during avian influenza epidemics (7).

Influenza viruses are transmittable from human to human, through aerosols produced through coughing or sneezing by the infected person. Furthermore, the virus can be transmitted through direct contact with the infected person, or through contact with contaminated surfaces or objects. The virus can spread quickly, is extremely contagious, and the incubation period is short. An infected person is contagious a day before and 5 to 10 days after the beginning of symptoms. Children can be contagious an even longer period, exposing people around them to the infection, especially in close communities. Immunodeficient persons can be contagious for weeks, even months (8). An epidemic will affect between $30 \%$ and $60 \%$ of the non immunized population.

\section{PHYSIOPATHOLOGY}

The flu represent the clinical manifestation of the influenza virus, in susceptible persons, who have inhaled contaminated aerosols. The absence of neutralizing antibodies allows for the multiplication of the virus at the cellular levels of the respiratory mucosa, which alters its function, and leads to cell lysis and the release of new virions. The clinical manifestations are the expression of the release of systemic inflammation mediators.

Incubation varies between 1 and 4 days, and the contagiousness is present a day before the clinical manifestation of symptoms, which makes the transmission of the virus possible from asymptomatic or paucisymptomatic people (9).

Virulence factors are represented by the surface proteins - haemagglutinin (HA) and neuraminidase (NA). These proteins subsequently become the target for specific antibodies. Haemagglutinin adheres to the surface of the epithelium allowing for cellular infection. neuraminidase has the role of cleaving the link between newly formed virions and the cellular surface, which favors the dissemination of infection (10).

Influenza virus is genetically unstable, having a rate of mutation 300 times higher compared to other microorganisms (11). The viral RNA-polymer- ase is deficient when it comes to the control mechanisms for transcription errors, which allows for antigenic drift type modifications. These types of mutations appear permanently, and are responsible of the virus' ability to annually avoid specific immune responses secondary to past influenza infections. Drift type antigen differences are reflected in the difference in virulence of strains. Antigenic drift takes place in the same subtype.

Antigenic shift is less frequent in involves the genetic reassortment of two strains, most probable during a coinfection of the same host organism. Antigenic shift takes place in a large susceptible population where more severe forms of illness are possible. The virulence of the strain is augmented and is more often responsible for pandemics.

\section{MATERNAL INFECTION}

\section{Risk factors}

Influenza infection in pregnant women usually has a more severe evolution. The risk of complications and unfavorable evolution seems to be lower in last trimester pregnancies and in the first four weeks postpartum (12).

\section{Clinical manifestations}

Influenza pandemics have allowed for the collection of useful data in regards to the clinical manifestations of influenza infection in pregnant women.

Before the AH1N1 influenza pandemic from 2009 , pregnant women were more likely to be hospitalized due to acute respiratory failure more often than non pregnant women (13).

At the same time, during the 2009 pandemic there was a disproportionate number of deaths in pregnant women ( $5 \%$ of the total registered deaths) in the USA (14).

Pregnant women are more at risk of being hospitalized in the ICU compared to the regular population (15). Evolution of the disease is more severe in pregnant women where antiviral therapy was delayed.

\section{The impact of influenza infections of the preg- nancy}

The effects of the influenza infection on pregnancy have not yet been studied. The transmission 
through the placental barrier seems to be rare (16). Even so, influenza infection in pregnancy could affect the fetus even in the absence of transplacental transmission through systemic effects which it triggers. In an observational study from 2013, influenza infections and other viral respiratory infections were associated with a higher risk of congenital malformations such as palatoschisis, hydrocephalus, neuronal development defects, cardiac malformations. Hipertermia and fever represent frequent clinical manifestations which increase the risk for disgravidia or fetus development problems (17). This risk seems to be minimised through the use of antipyretics. Other studies report correlations between influenza infection and miscarriage, premature birth, low birth weight and in utero fetus death (18). The influenza virus during the 2009 pandemic was associated with a high risk of fetal mortality, while immunization during pregnancy reduced the risk of developing the illness (19).

\section{Impactul of pregnancy on the virus}

Pregnant women are as likely to develop secondary complications as much as non pregnant women with comorbidities (Table 1) (20). The risk in higher with a higher pregnancy age (21).

TABLE 1. Categories of patients with a higher risk of complications

- Children < 5 years, and especially $<2$ years
- Adults > 65 years
- Pregnant women and postpartum women $<2$ weeks
- Patients with pathological antecedents:
- Asthma
- Neurological disorders
- Chronic respiratory disorders
- Cardiac disorders
- Haematological disorders
- Endocrinological disorders, includic diabetes mellitus
- Chronic renal disorders
- Chronic liver disorders
- Metabolic disorders
- Children < 19 years under chronic aspirin treatment
- Obesity (IMC $>40$ )

Primary viral pneumonia manifests when the viral infection especially affects the lungs and is usually severe. The persistence or the aggravation of the viral symptomatology, without a decline in symptoms - fever, dispnee, breathing problems and cianosis - are suggestive for this type of complication.
Secondary bacterial pneumonia is evident by the exacerbation of symptoms, after an initial improvement. Fever reappears and expectoration becomes productive. It has been demonstrated that the influenza virus favorizes the nasal colonization with $S$. pneumoniae, which seems to be the most frequent etiology of secondary influenza infections (22), followed by S. aureus (CA-MRSA) (23) and Haemophilus influenzae (22).

Myositis and rhabdomyolysis appear more frequently in children (24). Although myalgia is a symptom that defines influenza infections, myositis is less frequently observed. Even if viral load has been emphasised at the muscle cell level, the pathogenesis of myositis is not yet known. Intense muscular pain, especially in the legs, can be observed though laboratory tests through the elevation of creatine phosphokinase associated with myoglobinuria and acute renal failure (25).

Cardiac complications involve transitory EKG modifications, but also myocardial infarction, myocarditis and pericarditis. The risk of acute ischemic infarction is higher in the first seven days of illness, influenza B virus more frequently associated in this particular pathology than influenza A virus, and three times more frequently than syncytial respiratory virus (26).

Central nervous system complication include encephalopathy, encephalitis, transverse myelitis, aseptic meningitis and Guillain-Barré syndrome.

Toxic shock syndrome has been described in influenza patients - especially influenza B virus infections - who associate $S$. aureus infections (27).

\section{Prenatal diagnosis}

Diagnosis of influenza in pregnant women involves the same steps as in the regular population, except the pulmonary X-ray.

Clinical diagnosis during an influenza epidemic is suggested by any respiratory disease with fever, with a probability of $79 \%$, that involves at least two of the four other symptoms: cough, myalgia, odynophagia and headache (28). Outside season epidemics, influenza A and B viruses account for only $10 \%$ of viral respiratory infections etiology, after rhinovirus (52\%) and coronavirus (26\%), and clinical diagnosis is difficult to establish (29).

Laboratory diagnosis involves the confirmation of the initial clinical supposition through various 
TABLE 2. Diagnostic tests for influenza virus

\begin{tabular}{|l|l|l|l|}
\hline Test & $\begin{array}{l}\text { Time until } \\
\text { positive result }\end{array}$ & Biological material & Comments \\
\hline $\begin{array}{l}\text { Conventional RT-PCR and other } \\
\text { molecular tests }\end{array}$ & $1-8$ hours & $\begin{array}{l}\text { Naso-oropharyngeal exudate, } \\
\text { bronchial lavage, tracheal } \\
\text { aspirate; }\end{array}$ & $\begin{array}{l}\text { High sensibility and specificity; recommended; } \\
\text { can differentiate between influenza A and B virus } \\
\text { as well as subtypes; }\end{array}$ \\
\hline $\begin{array}{l}\text { Quick molecular tests (detect } \\
\text { viral RNA) }\end{array}$ & $<20$ min & $\begin{array}{l}\text { Nasal exudate, pharyngeal } \\
\text { exudate; }\end{array}$ & $\begin{array}{l}\text { High sensibility and specificity; recommended; } \\
\text { can differentiate between influenza A and B virus } \\
\text { but not subtypes }\end{array}$ \\
\hline Immunofluorescence & $1-4$ hours & $\begin{array}{l}\text { Naso-oropharyngeal exudate, } \\
\text { bronchial lavage, tracheal } \\
\text { aspirate; }\end{array}$ & $\begin{array}{l}\text { Moderate sensibility, high specificity; } \\
\text { recommended; can differentiate between } \\
\text { influenza A and B virus and other viral types; }\end{array}$ \\
\hline $\begin{array}{l}\text { Quick detection of } \\
\text { viral antigen through } \\
\text { immunochromatography }\end{array}$ & $10-15$ min & Naso-pharyngeal exudate & $\begin{array}{l}\text { Moderate sensibility, high specificity; can } \\
\text { differentiate between influenza A and B virus as } \\
\text { well as subtypes; }\end{array}$ \\
\hline $\begin{array}{l}\text { Quick tests (detection of viral } \\
\text { antigen or neuraminidase) }\end{array}$ & $<15$ min & Naso-pharyngeal exudate & $\begin{array}{l}\text { Low sensibility and low/medium specificity; } \\
\text { recommended; a negative test does not exclude } \\
\text { an infection; }\end{array}$ \\
\hline $\begin{array}{l}\text { Viral culture } \\
\text { Viral envelope culture } \\
\text { Isolation from celular cultures }\end{array}$ & $\begin{array}{l}24-72 \text { hours } \\
3-10 \text { days }\end{array}$ & $\begin{array}{l}\text { Naso-oropharyngeal exudate, } \\
\text { bronchial lavage, tracheal } \\
\text { aspirate; special transport } \\
\text { medium; }\end{array}$ & $\begin{array}{l}\text { Moderate/high sensibility and high specificity; } \\
\text { recommended for screening confirmation and in } \\
\text { management; }\end{array}$ \\
\hline $\begin{array}{l}\text { Serological tests } \\
\text { manalth management; not useful in clinical }\end{array}$ & $\begin{array}{l}\text { Serum } \\
\text { matrospective diagnosis; }\end{array}$ \\
\hline
\end{tabular}

tests, adjusted to the possibilities of the medical center.

Out of the molecular tests, RT-PCR is the most sensitive and specific diagnostic tests, with quick results, which also establishes viral subtype (Table 2).

Quick molecular tests provide fast results, under 20 minutes, in the ER, with a sensibility of $80 \%$ for influenza $\mathrm{A}$ and $77 \%$ for influenza $\mathrm{B}$, compared to classical molecular tests where sensibility varies between $92 \%$ and $95 \%$ for influenza $\mathrm{A}$ and $\mathrm{B}$ respectively (30).

Quick antigen tests are based on immunoserological methods of detection of necleoprotidic viral antigens in biological material taken from the respiratory passage. The tests give results in approximately 15 minutes but with a much lower sensibility compared to RT-PCR or quick molecular tests, of almost 53-54\% (30).

Direct or indirect immunofluorescence tests detect the presence of viral antigens, but have a low sensibility and specificity.

Digital immune tests ((Digital immunoassay DIAs) are quick tests that detect the presence of antigens though immunochromatography. Results are available in 1-15 minutes (31) with a sensibility of approximately $80 \%$ (32).

Viral culture is considered a traditional "gold standard" for a certified diagnosis, but takes up to
48-72 hours until positive results. It is not used as a routine diagnosis rests, but as a screening tests and for public health management.

Serological tests are not useful for the diagnosis of an acute infection, because it involves the prelevation of materials form both the acute phase of illness as well as post infection, which determine the antibody levels in dynamic. It is useful for a retrospective diagnosis in clinical studies.

\section{MANAGEMENT OF INFLUENZA INFECTION DIAGNOSIS DURING PREGNANCY}

Treatment should begin promptly, from the very first suggestive symptoms, indiferent of the immunization status, considering vaccination is not $100 \%$ efficient (33). Empirical treatment can be initiated in relation to the activity of the virus in the community in that respective moment.

Pregnant or postpartum women under 2 weeks, who have symptoms suggestive of the flu, require prompt empirical treatment with antiviral medication. The initiation of treatment as quick as possible, in the first days of symptoms, is associated with less severe forms of illness and a lower mortality index. Other studies confirm the benefit of treatment initiated after 2 days of illness. The risk of antiviral medications is considered low com- 
pared to the benefits, especially in pregnant women with severe forms of illness (34).

If the partner is diagnosed with influenza during pregnancy, there are no side effects associated to the fetus as well as in the development of assisted reproduction procedures.

Currently there is a new antiviral agent - Baloxavir marboxil - that is FDA approved starting with october 2018 after phase III studies, from which pregnant women have been excluded. Until more data is made possible and the safety of the drug is proven, oseltamivir remains the choice of first line antiviral therapy.

\section{Antivirals}

Neuraminidase inhibitors currently in use are: oseltamivir - oral administration, zanamivir - inhalation administration and peramivir - intravenous administration. Oseltamivir, although class $\mathrm{C}$, is the preferred treatment, assuming the low prevalence of viral resistance. Doses are the same as in the general population: Oseltamivir $75 \mathrm{mg}$ every 12 hours for 5 days; Zanamivir $10 \mathrm{mg} 2$ inhalations per day, 5 days; Peramivir $600 \mathrm{mg}$ iv in 15-30 minutes as a single dose (35). Treatment can be prolonged in more severe forms of illness, over 5 days, some clinicians recommending a double dose (Oseltamivir $150 \mathrm{mg} / \mathrm{zi}$ ) although there is no clinical proof of a higher benefit with a higher dose (36).

The intravenous form of viral medication has been approved by the FDA in 2014 for Peramivir, and currently there is work on an intravenous formulation of Zanamivir. Data to prove the efficiency of iv medication are lacking currently, but oseltamivir administered in severe forms via nasogastric tube seems to be absorbed in a sufficient concentration for favorable results.

\section{Antipyretics}

Acetaminofen (paracetamolul) is the preferred treatment of fever, considering the fact that hyperthermia in the first trimester of pregnancy is associated with neural tube defects or other congenital malformations. Furthermore, the presence of fever during labor is a risk factor for neo natal convulsions, encephalopathy, paralysis, or death (37). Other antipyretics (aspirin, ibuprofen) were associated with diverse adverse effects in the newborn, which is a reason why they're not advised in pregnancy.

\section{Antibiotics}

Antibiotic treatment is only indicated in special cases of overlaid bacterial infection of the superior respiratory tract (sinusitis, otitis) and inferior respiratory tract (pneumonia). Treatment is similar with that in the general population, but taking into account the teratogenic potential of certain antibiotics which should be avoided in pregnant women (Table 3).

TABLE 3. Antibiotics not indicated in pregnancy

\begin{tabular}{l} 
- Tetracyclines \\
- Tigeciclina \\
- Elarithromycin \\
- Eluoroquinolones \\
- Cloranfenicol \\
- Aminoglycosides \\
\hline
\end{tabular}

Pregnant women that develop secondary pneumonia are predisposed for an earlier birth (38), and are at a higher risk for pulmonary edema. It is then of utmost importance that bacterial pneumonia as a complication of influenza infection should be treated promptly. Pregnant women are predisposed to developing pneumonia because of physiological changes that take place during pregnancy: the ascension of the diaphragma up to $4 \mathrm{~cm}$, the decline residual capacity, the rise in oxygen consumption and water and salt retention at the pulmonary level. The treatment of pneumonia in pregnant women is summarized in Table 4.

Community acquired pneumonia in its less severe form should be treated with associated amoxicillin-clavulanate and azithromycin. Hospitalized patients should receive an association of beta lactamines (ceftriaxone, cefotaxime, ampicillin-sulbactam) and azithromycin, and severe forms require vancomycin as an anti-staphylococcal and anti-pneumococcal agent.

Breastfeeding is not contraindicated. The virus is not transmittable through breastfeeding. During the respiratory phase, the mother will transmit maternal antibodies to the newborn, offering immunization, if she isn't hospitalized. In cases requiring hospitalization and the separation of mother and newborn, the mother should be encouraged to 
maintain lactation. Oseltamivir is transmitted through breast milk at a very low dose and does not affect the newborn (39), which is why breastfeeding is encouraged in new mothers with influenza even if they are under antiviral treatment.

TABLE 4. Algorithm for treatment of pneumonia in pregnant women

1. Direction for pulmonary X-Ray is the same in pregnant women as in non-pregnant women;

2. $\mathrm{O}_{2}$ administration for maintaining a peripheral saturation of $>95 \%$ or $\mathrm{pO}_{2}>70 \mathrm{mmHg}$. Careful and constant monitoring is advised;

3. Monitoring of acid-base balance (ABB), especially in case of suspected of $\mathrm{CO}_{2}$ retention (a $\mathrm{pCO}_{2}$ in pregnancy in normally $25-33 \mathrm{mmHg}$; any $\mathrm{pCO}_{2}$ of $35 \mathrm{mmHg}$ represents a retention of $\mathrm{CO}_{2}$ and suggests respiratory failure;

4. Fever is treated with acetaminophen;

5. Monitoring in an obstetric-gynecological service;

6. Close monitoring of hidroelectrolitic balance, because patients are at risk of developing pulmonary edema;

7. Blood cultures and sputum collection for bacteriological examination;

8. Out of the indicated antibiotics, tetracyclines, fluoroquinolones and clarithromycin.

- For primary community-associated pneumonia, mild forms, beta lactam therapy (ceftriaxone, cefotaxime, ampicillin- sulbactam) associated with azithromycin.

- Patients allergic to cephalosporins can be treated with clindamycin associated with aztreonam;.

- Severe forms recommend the association of vancomycin with azithromycin and aztreonam;

9. If deemed necessary, serological testing for Mycoplasma $\mathrm{sp}$, Chlamydia and Legionella sp urinary antigen and pneumococcus.

10. Anticipate the possibility and indication for orotracheal intubation and make sure the necessary equipment is on hand

11. Correctly position the patient so to avoid the obstruction of venous circulation by the pregnancy (left lateral decubitus).

12. Bronchoscopy if this test is able to offer important information in regards to patient management;

13. For patient who are immobilized, deep vein thrombosis prophylaxis is recommended.

\section{PROPHYLAXY}

\section{Vaccination}

Starting with 2014, the CDC recommended immunization of all pregnant women with inactivated virus vaccine, regardless of trimester (40). Currently there are two types of vaccines available commercially: tetravalent (2 strains influenza $A$ and 2 strains influenza B) and trivalent (2 strains influenza $A$ and 1 strain influenza $B$ ), either preferred in pregnancy in absence of comparative data. A recombinant vaccine without egg protein is available for people with egg allergies, including pregnant women (41).
Although immunization recommendations are unanimously accepted, the rate of immunization in pregnant women remains low, only $36 \%$ in november 2017 in the USA (42). The rate of immunisation increases if personal practitioners recommend and administer the vaccine themselves.

Immunization is not $100 \%$ efficient, but reduces the risk of developing the acute illness. Pregnant women develop passive immunity in equal measure compared with regular population (43), although there are certain differences in the immune response in pregnancy (44). Some studies have demonstrated that immunization through vaccination has been associated with a reduced risk of pregnancy stopping in evolution, but has no effect on miscarriage (45).

Immunization protects the mother, but also the newborn for the first months after birth (46). Immunization involves the development of anti-influenza IgG antibodies, which traverse the placenta (47), protecting the newborn after birth, as well IgA antibodies which the mother transfers to the child through breastfeeding (48). Because of this, immunization of pregnant women becomes an important instrument in the prophylaxis of influenza infections in newborns, considering they are exposed to a higher risk of contracting the virus and developing more severe forms of disease and they are not eligible for direct immunization through vaccination until 6 months because of a insufficient and inefficient immune response (49). In a study in Bangladesh, the vaccination of pregnant women in the last trimester of pregnancy led to a $63 \%$ decrease in the risk of newborns developing the disease in the first 6 months of life (50).

Even though in the general population, but especially in pregnant populations there are certain worries in regards to the adverse effects of vaccination, numerous studies have proved that the change of these side effects is low. Even though vaccination is associated with a low risk of Guillain-Barré syndrome, the risk/benefit balance is in favour of influenza immunization (51). One single study seems to support the evidence of a possible correlation between miscarriage and vaccination with the product containing the strain H1N1pdm09, administered in the period of 2010-2011 and 2011-2012, but this data needs confirmation through further studies (52). 


\section{ALGORITHM FOR MANAGEMENT OF INFECTION}

Unvaccinated pregnant women are exposed to a higher risk (Fig. 1) of developing severe secondary complications associated with influenza virus infection which might need admission in the ICU.

\section{Confirmă gripa clinic}

Tabloul clinic include febră $>37.8^{\circ} \mathrm{C}$, plus cel puțin unul dintre urmatoarele criterii:

- tuse

- odinofagie

- rinoree

- cefalee sau mialgii

- astenie

- dispnee

- diaree sau vărsături

- dacă pacienta nu este febrilă dar cu debut acut al simptomatologiei sugestive pentru gripă, continua conform algoritmului

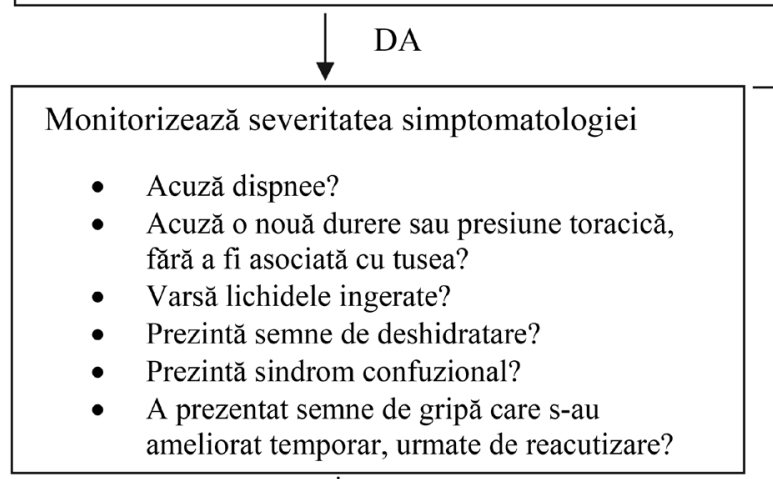

$\mathrm{NU}$
Oricare răspuns pozitiv

- Comorbidități (HIV, astm)

- Disgravidie

- Imposibilitatea de a se îngriji singură

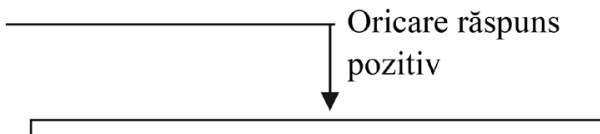

\section{RISC CRESCUT}

Recomandă consult imediat în serviciul de urgență. Dacă este posibil, îndrumă pacienta într-un serviciu în care poate fi izolată. Se va iniția tratament antiviral conform ghidurilor actuale.

\section{RISC MODERAT}

Pacienta va fi examinată în ambulator pentru aprecierea severităţii afecțiunii. Dacă este posibil, îndrumă pacienta într-o unitate în care poate fi izolată.

Monitorizează funcția respiratorie clinic (SaO2), radiologic sau şi echilibrul acidobazic.

Inițiază tratamentul antiviral conform ghidurilor actuale.

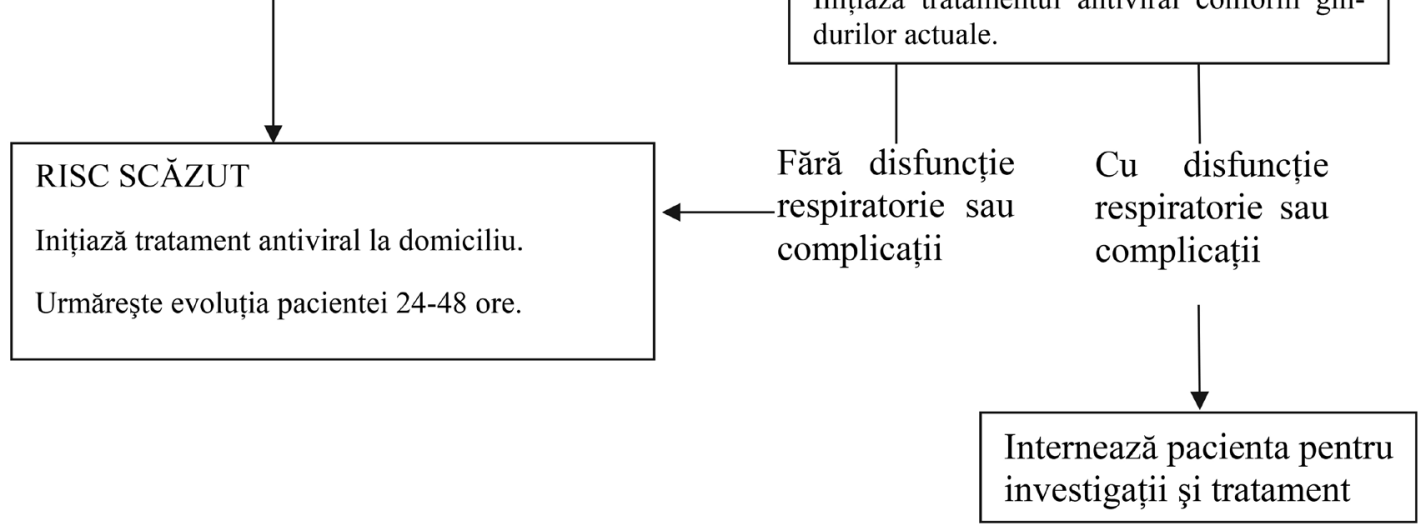




\section{POSOLOGY OF RECOMMENDED TREATMENT}

\begin{tabular}{|l|l|}
\hline Antiviral agent & Dose \\
\hline Oseltamivir & \\
\hline $\begin{array}{l}\text { Treatment for influenza A } \\
\text { and B }\end{array}$ & $\begin{array}{l}75 \mathrm{mg} \text { every } 12 \text { hours po, } \\
5 \text { days }\end{array}$ \\
\hline $\begin{array}{l}\text { Prophylaxis for influenza A } \\
\text { and B }\end{array}$ & $75 \mathrm{mg}$ po once a day, 10 days \\
\hline Zanamivir & $\begin{array}{l}10 \mathrm{mg} \mathrm{(2} \text { inhalations) every } 12 \\
\text { hours po, } 5 \text { days }\end{array}$ \\
\hline $\begin{array}{l}\text { Treatment for influenza A } \\
\text { and B }\end{array}$ & $\begin{array}{l}10 \mathrm{mg}(2 \text { inhalations) daily, } \\
10 \text { days }\end{array}$ \\
\hline $\begin{array}{l}\text { Prophylaxis for influenza A } \\
\text { and B }\end{array}$ & $600 \mathrm{mg}$ i.v. single dose \\
\hline Peramivir & $\begin{array}{l}\text { Treatment for influenza A } \\
\text { and B }\end{array}$ \\
\hline
\end{tabular}

\section{REFERENCES}

1. http://www.virology.net/Big_Virology/BVRNAortho.html

2. https://www.cdc.gov/flu/about/viruses/types.htm

3. E Azziz Baumgartner, CN Dao, S Nasreen, et al.: Seasonality, timing, and climate drivers of influenza activity worldwide. J Infect Dis. 206:838-8462012 PMID:22829641

4. S Saha, M Chadha, AAl Mamun, et al.: Influenza seasonality and vaccination timing in tropical and subtropical areas of southern and south-eastern Asia. Bull World Health Organ. 92:318-330 2014 PMID:24839321

5. JD Tamerius, J Shaman, WJ Alonso, et al.: Environmental predictors of seasonal influenza epidemics across temperate and tropical climates. PLoS Pathog. 9:e1003194 2013 PMID:23505366

6. Weekly epidemiological record, nos. 51/52, 16 december 2016)

7. Avian influenza ("bird flu"): fact sheet. World Health Organization. Available at http://www.who.int/mediacentre/factsheets/avian_influenza/en/print.html

8. World Health Organization Writing Group, Bell D, Nicoll A et al. Non-pharmaceutical interventions for pandemic influenza, international measures. Emerg Infect Dis. 2006 Jan. 12 (1):81-7. [Medline]. [Full Text]

9. Gu Y, Komiya N, Kamiya H, Yasui Y, Taniguchi K, Okabe N. Pandemic (H1N1) 2009 transmission during presymptomatic phase, Japan. Emerg Infect Dis. 2011 Sep. 17(9):1737-9.

10. Gubareva LV, Kaiser L, Hayden FG. Influenza virus neuraminidase inhibitors. Lancet. 2000 Mar 4. 355(9206):827-35

11. Drake JW. Rates of spontaneous mutation among RNA viruses. Proc Natl Acad Sci U S A. 1993 May 1. 90(9):4171-5

12. Mertz D, Kim TH, Johnstone J et al. Populations at risk for severe or complicated influenza illness: systematic review and meta-analysis. BMJ 2013; 347:f5061

13. Dodds $L$, McNeil SA, Fell DB et al. Impact of influenza exposure on rates of hospital admissions and physician visits because of respiratory illness among pregnant women. CMAJ 2007; 176:463).

14. Siston AM, Rasmussen SA, Honein MA et al. Pandemic 2009 influenza $\mathrm{A}(\mathrm{H} 1 \mathrm{~N} 1)$ virus illness among pregnant women in the United States. JAMA 2010; 303:1517.

15. Meijer WJ, van Noortwijk AG, Bruinse HW, Wensing AM. Influenza virus infection in pregnancy: a review. Acta Obstet Gynecol Scand 2015; 94:797.

16. Irving WL, James DK, Stephenson T et al. Influenza virus infection in the second and third trimesters of pregnancy: a clinical and seroepidemiological study. BJOG 2000; 107:1282.

17. Luteijn JM, Brown MJ, Dolk H. Influenza and congenital anomalies: a systematic review and meta-analysis. Hum Reprod 2014; 29:809.
Conflict of interest: none declared Financial support: none declared
18. Centers for Disease Control and Prevention (CDC). Maternal and infant outcomes among severely ill pregnant and postpartum women with 2009 pandemic influenza A (H1N1)--United States, April 2009-August 2010. MMWR Morb Mortal Wkly Rep 2011; 60:1193

19. Håberg SE, Trogstad L, Gunnes $N$ et al. Risk of fetal death after pandemic influenza virus infection or vaccination. N Engl J Med 2013; 368:333

20. Centers for Disease Control and Prevention. People at high risk of developing flu-related complications. www.cdc.gov/flu/about/disease/ high_risk.htm

21. http://www.influenza.org.nz/impact-influenza-infection-during-pregnancy

22. Bacterial pneumonia during the Hong Kong influenza epidemic of 1968-1969. Schwarzmann SW, Adler JL, Sullivan RJ Jr, Marine WM Arch Intern Med. 1971;127(6):1037

23. S. aureus community-acquired pneumonia during the 2006 to 2007 influenza season. Kallen AJ, Brunkard J, Moore Z, Budge P, Arnold KE, Fosheim G, Finelli L, Beekmann SE, Polgreen PM, Gorwitz R, Hageman J Ann Emerg Med. 2009;53(3):358

24. Acute myositis associated with influenza $B$ infection. Dietzman DE, Schaller JG, Ray CG, Reed ME Pediatrics. 1976;57(2):255

25. Clinical study of influenza-associated rhabdomyolysis with acute renal failure. Abe M, Higuchi T, Okada K, Kaizu K, Matsumoto K Clin Nephrol. 2006;66(3):166.

26. Acute Myocardial Infarction after Laboratory-Confirmed Influenza Infection. Kwong JC, Schwartz KL, Campitelli MA, Chung H, Crowcroft NS, Karnauchow T, Katz K, Ko DT, McGeer AJ, McNally D, Richardson DC, Rosella LC, Simor A, Smieja M, Zahariadis G, Gubbay JB N Engl J Med. 2018;378(4):345

27. Toxic shock syndrome complicating influenza $A$ in a child: case report and review. Tolan RW Jr Clin Infect Dis. 1993;17(1):43

28. Predicting influenza infections during epidemics with use of a clinical case definition. Boivin G, Hardy I, Tellier G, Maziade J Clin Infect Dis. 2000;31(5): 1166

29. Acute viral infections of upper respiratory tract in elderly people living in the community: comparative, prospective, population based study of disease burden. Nicholson KG, Kent J, Hammersley V, Cancio E BMJ. 1997;315(7115):1060.)

30. Diagnostic Accuracy of Novel and Traditional Rapid Tests for Influenza Infection Compared With Reverse Transcriptase Polymerase Chain Reaction: A Systematic Review and Meta-analysis. Merckx J, Wali R, Schiller I, Caya C, Gore GC, Chartrand C, Dendukuri N, Papenburg J Ann Intern Med. 2017;167(6):394. Epub 2017 Sep 5. 31. Can newly developed, rapid immunochromatographic antigen 
detection tests be reliably used for the laboratory diagnosis of influenza virus infections? Dunn JJ, Ginocchio CC J Clin Microbiol. 2015;53(6):1790. Epub 2014 Oct 1

32. Diagnostic Accuracy of Novel and Traditional Rapid Tests for Influenza Infection Compared With Reverse Transcriptase Polymerase Chain Reaction: A Systematic Review and Meta-analysis. Merckx J, Wali R, Schiller I, Caya C, Gore GC, Chartrand C, Dendukuri N, Papenburg J Ann Intern Med. 2017;167(6):394. Epub 2017 Sep 5).

33. 2009 pandemic influenza $A(H 1 N 1)$ and vaccine failure in pregnancy. Louie JK, Wadford DA, Norman A, Jamieson DJ Obstet Gynecol. 2011;117(2 Pt 2):470)

34. Severity of 2009 pandemic influenza A (H1N1) virus infection in pregnant women. Creanga AA, Johnson TF, Graitcer SB, Hartman LK, Al-Samarrai T, Schwarz AG, Chu SY, Sackoff JE, Jamieson DJ, Fine AD, Shapiro-Mendoza CK, Jones LE, Uyeki TM, Balter S, Bish CL, Finelli L, Honein MA Obstet Gynecol. 2010;115(4):717

35. http://www.cdc.gov/flu/professionals/antivirals/summary-clinicians. $\mathrm{htm}$

36. Antiviral agents for the treatment and chemoprophylaxis of influenza --- recommendations of the Advisory Committee on Immunization Practices (ACIP). Fiore AE, Fry A, Shay D, Gubareva L, Bresee JS, Uyeki TM, Centers for Disease Control and Prevention (CDC) MMWR Recomm Rep. 2011;60(1):1)

37. (Review: Hyperthermia and fever during pregnancy. Edwards MJ Birth Defects Res A Clin Mol Teratol. 2006;76(7):507

38. Maternal acute respiratory infectious diseases during pregnancy and birth outcomes. Bánhidy F, Acs N, PuhóEH, Czeizel AE Eur J Epidemiol. 2008;23(1):29-35. Epub 2007 Nov 20

39. Oseltamivir and breastfeeding. Wentges-van Holthe $\mathrm{N}$, van Eijkeren M, van der Laan JW Int J Infect Dis. 2008;12(4):451. Epub 2008 Feb 1

40. Prevention and Control of Seasonal Influenza with Vaccines: Recommendations of the Advisory Committee on Immunization Practices - United States, 2017-18 Influenza Season. Grohskopf LA, Sokolow LZ, Broder KR, Walter EB, Bresee JS, Fry AM, Jernigan DB MMWR Recomm Rep. 2017;66(2):1. Epub 2017 Aug 25

41. Influenza vaccination coverage among pregnant women--United States, 2012-13 influenza season. Centers for Disease Control and Prevention (CDC) MMWR Morb Mortal Wkly Rep. 2013;62(38):787).
42. Centers for Disease Control and Prevention. Pregnant women and flu vaccination, Internet Panel Survey, United States, November 2017. https://www.cdc.gov/flu/fluvaxview/pregnant-women-nov2017. $\mathrm{htm}$

43. Benefits of influenza vaccination during pregnancy for pregnant women. Jamieson DJ, Kissin DM, Bridges CB, Rasmussen SA Am J Obstet Gynecol. 2012 Sep;207(3 Suppl):S17-20. Epub 2012 Jul 9

44. Pregnancy modifies the antibody response to trivalent influenza immunization. Schlaudecker EP, McNeal MM, Dodd CN, Ranz JB, Steinhoff MC J Infect Dis. 2012;206(11):1670. Epub 2012 Sep 14

45. Maternal influenza immunization and birth outcomes of stillbirth and spontaneous abortion: a systematic review and meta-analysis. Bratton KN, Wardle MT, Orenstein WA, Omer SB Clin Infect Dis. 2015 Mar;60(5):e11-9. Epub 2014 Nov 18

46. Influenza in Infants Born to Women Vaccinated During Pregnancy. Shakib JH, Korgenski K, Presson AP, Sheng X, Varner MW, Pavia AT, Byington CL Pediatrics. 2016;137(6) Epub 2016 May 2

47. Prevalence of influenza $A$ and $B$ antibodies in pregnant women and their offspring.Wutzler P, Schmidt-Ott R, Hoyer H, Sauerbrei A J Clin Virol. 2009 Oct;46(2):161-4)

48. IgA and neutralizing antibodies to influenza a virus in human milk: a randomized trial of antenatal influenza immunization. Schlaudecker EP, Steinhoff MC, Omer SB, McNeal MM, Roy E, Arifeen SE, Dodd CN, Raqib R, Breiman RF, Zaman K PLoS One. 2013;8(8):e70867. Epub 2013 Aug 14

49. Immunization of high-risk infants younger than 18 months of age with split-product influenza vaccine. Groothuis JR, Levin MJ, Rabalais GP, Meiklejohn G, Lauer BA Pediatrics. 1991;87(6):823

50. K Zaman, E Roy, SE Arifeen, et al.: Effectiveness of maternal influenza immunization in mothers and infants. N Engl J Med. 359:1555-1564 2008 PMID: 18799552

51. Risk of Guillain-Barrésyndrome following H1N1 influenza vaccination in Quebec. De Wals P, Deceuninck G, Toth E, Boulianne N, Brunet D, Boucher RM, Landry M, De Serres G JAMA. 2012 Jul;308(2):175-81

52. Association of spontaneous abortion with receipt of inactivated influenza vaccine containing H1N1pdm09 in 2010-11 and 2011-12. Donahue JG, Kieke BA, King JP, DeStefano F, Mascola MA, Irving SA, Cheetham TC, Glanz JM, Jackson LA, Klein NP, Naleway AL, Weintraub E, Belongia EA Vaccine. 2017;35(40):5314 